\title{
ARTicle
}

\section{Environmental Inspections and the EU: Securing an Effective Role for a Supranational Union Legal Framework}

\author{
Martin Hedemann-Robinson*
}

\begin{abstract}
Over several years, the European Union (EU) has gradually developed its legal framework to assist in the proper application of Union environmental protection rules, both at Member State as well as EU institutional levels. This article focuses on one particular and relatively recent emerging element of that supranational framework, namely the range of EU secondary legislative measures and provisions concerning the management of environmental inspections. In addition to appraising the extent of Union legislative engagement in relation to environmental inspections, it also reflects on certain challenges of a constitutional nature that the EU will need to address in the future if its intervention in this particular policy field continues to develop.
\end{abstract}

Keywords: Environmental inspections, European Union Law, Implementation, Subsidiarity, Administrative cooperation

\section{INTRODUCTION}

A significant long-standing and well-known challenge to the authority of European Union (EU) environmental law has been how best to enhance the relatively poor state of implementation of its norms in the Union's Member States. Reports over the years from bodies monitoring the application of EU environmental policy such as the European 
Commission $^{1}$ and the European Environment Agency $(E E A)^{2}$ have repeatedly shown that EU

Member States, who are made chiefly responsible for the implementation of Union

environmental policy at national level under the Union's principal foundational treaties of the Treaty on European Union (TEU) and Treaty on the Functioning of the EU (TFEU), ${ }^{3}$ have on many occasions fallen short when it comes to securing the proper application of their EU environmental statutory responsibilities. The EU network of environmental authorities known as 'IMPEL" ${ }^{4}$ has recently reported its concerns regarding the wide variation in the quality and effectiveness of national competent authority structures across the EU Member States in the environmental sector. ${ }^{5}$ Problems concerning the state of implementation of EU environmental law have also been the subject of substantial and long-standing academic commentary. ${ }^{6}$ This article focuses on one particular area of implementation of EU environmental protection rules, namely, inspection controls. It assesses and reflects upon the extent to which the EU has developed a supranational legal framework concerning the management of environmental inspections for the purpose of assisting in overseeing compliance with EU environmental legislation.

\footnotetext{
${ }^{1}$ For example, annual reports completed by the European Commission monitoring compliance with Union environmental law confirmed that between 2002-2013 the environmental sector constituted the largest proportion of infringement actions pursued by the Commission in all but one of those years: see analysis by $\mathrm{M}$. Hedemann-Robinson, Enforcement of European Union Environmental Law: Legal Issues and Challenges 2nd ed (Routledge, 2015) at pp247-248. (European Commission annual monitoring reports are available for inspection at http://ec.europa.eu/atwork/applying-eu-law/infringements-proceedings/annualreports/index_en.htm). In its 2011 study on implementation of EU environmental legislation for the European Commission, the Danish environmental consultancy COWI estimated that the annual cost of nonimplementation of the EU's environmental acquis amounted to some $€ 50 \mathrm{bn}$ (COWI The Costs of not implementing the environmental acquis (September 2011) - Final Report (ENV.G.1/FRA/2006/0073): available for inspection at: http://ec.europa.eu/environment/enveco/economics_policy/pdf/report_sept2011.pdf).

${ }^{2}$ For example, in 2014 the EEA reported that in the region of $21 \%, 14 \%$ and $8 \%$ of the EU-28 urban population resides in areas where the exposure to particular matter (PM10), ozone (O2) and nitrogen dioxide (NO2) exceeds maximum EU limit values: see EEA Report No5/2014 Air quality in Europe - 2014 report, 19.11.2014 (ISSN 1725-9177) (Report available for inspection at: http://www.eea.europa.eu/publications/airquality-in-europe-2014).

${ }^{3}$ See Art.192(4) TFEU, which stipulates that 'without prejudice to certain measures adopted by the Union, Member States shall [...] implement the environment policy'. See also the general obligations of Member States set down by the TEU and TFEU on implementing EU law: Art.4 (3) TEU and Arts.197 (1) and 291(1) TFEU.

${ }^{4}$ EU Network for the Implementation and Enforcement of Environmental Law: $\underline{\mathrm{http}}$ ://impel.eu/

${ }^{5}$ IMPEL Final Report Challenges in the Practical Implementation of EU Environmental Law and how IMPEL could help overcome them, 23.3.2015. A 2009 IMPEL study assessed that in the region of $19 \%$ of transboundary waste shipments in the Union were illegal: ESWI Consortium (2009) IMPEL-TFS Enforcement Actions II Enforcement of EU waste Shipment Regulation “Learning by Doing”, Interim Project Report (12.10.2009). (All reports are available for inspection on the IMPEL website: http://impel.eu).

${ }^{6}$ See e.g. L. Borzsák, The Impact of Environmental Concerns on the Public Enforcement Mechanism under EU Law: Environmental Protection in the $25^{\text {th }}$ Hour (2011, Kluwer); P. Davies, EU Environmental Law: A Introduction to Selected Issues (Ashgate, 2004); M. Hedemann-Robinson (2015) n.1 above; M. HedemannRobinson, 'Enforcement of EU Environmental Law: Taking Stock of the Evolving Union Legal Framework' (2015) European Energy and Environmental Law (forthcoming); L. Krämer, EU Environmental Law $7^{\text {th }}$ ed. ( Sweet \& Maxwell, 2011), K. Lenaerts \& J. Gutierrez-Fons, 'The General System of EU Environmental law Enforcement' (2011) 30(1) Yearbook of European Law 3; P. Wennerås, The Enforcement of EC Environmental Law (OUP, 2007).
} 
Inspection systems constitute an integral and vital part of regulatory frameworks constructed for the purpose of overseeing compliance with minimum standards of conduct prescribed by public law. As noted generally by Baldwin, Cave and Lodge, 'uncovering undesirable behaviour through detection is a first step in regulatory enforcement' ${ }^{7}$ Environmental regulation is no different in this respect. The establishment of an efficient system of inspection controls is crucial for regulators to be in a position to supervise compliance with environmental protection rules effectively. For several years, though, the quality and effectiveness of national environmental inspectorate systems across the EU has varied considerably, which undermines of the uniformity of application as well as integrity of EU environmental legislative commitments. Whilst the Union was initially reluctant to intervene in areas concerned with national administrative supervision of EU environmental policy, over time this stance has changed considerably. A range of EU legislative measures have been adopted, principally since the early 2000s, with a view to involving the Union more closely in supervising the way in which the implementation of EU environmental law is administered at national level, including in the area of inspections. Most recently, the adoption of the Union's Seventh Environment Action Programme 2013-2020 (EAP7) has placed the issue of EU level engagement in environmental inspections into the political foreground by virtue of a specific commitment to introduce 'binding criteria' for effective Member State inspections as well as development of inspection support capacity at Union level. ${ }^{8}$ This political stimulus injected by EAP7 follows on from a series of relatively recent EU environmental legislative instruments that contain minimum inspection standards. Such measures have been, though, politically controversial amongst several Member State governments keen to reserve implementation tasks as far as possible as matters of national sovereign competence. The policy area of environmental inspections remains a heavily contested terrain from an EU constitutional perspective, in which the balance of power and responsibilities between EU federal and national levels has yet to be settled with adequate clarity or certainty.

In exploring the Union's engagement with the subject of environmental inspections management, this article is divided into two principal parts. Section 2 focuses in detail on the extent to which specific EU measures have been introduced to enhance systems of

\footnotetext{
${ }^{7}$ R. Baldwin, M. Cave \& M. Lodge, Understanding Regulation: Theory Strategy and Practice $2^{\text {nd }}$ ed. (OUP, 2012) at p228.

${ }^{8}$ Paragraph 65(iii) of Annex to Decision 1386/2013 on a General Union Environment Action Programme to 2020 'Living well, within the limits of our planet' [2013] OJ L354/171.
} 
environmental inspection, both in terms of inspections carried out by national authorities as well as by Union bodies. In addition, it considers the potential impact of EAP7, taking into account the most recent EU institutional involvement in policy development on inspections. Section 3 places the issue of an emerging EU inspections policy in a broader regulatory context. It reflects upon the political and legal challenges that are liable to affect the degree to which future EU level intervention in this area may be readily accommodated within the current system of decentralized administration of EU environmental law. It takes into account certain new constraints on Union competence to intervene in implementation issues introduced by virtue of the amendments of the 2007 Lisbon Treaty ${ }^{9}$ to the Union's foundational legal architecture. ${ }^{10}$ These concern recent EU treaty changes regarding the application of the subsidiarity principle as well as new Treaty provisions concerning administrative co-operation with Member State authorities. The final part to this article offers concluding remarks on the nature and state of legal evolution concerning Union policy involvement in environmental inspection matters.

\section{ENVIRONMENTAL INSPECTIONS AND EU LAW}

The area of environmental inspections is a policy topic that the EU has only relatively recently begun to address in some degree of earnest. There have been long-standing concerns about the effectiveness of a number of environmental inspectorate systems in several Member States. Varies studies (such as those sponsored by the European Commission ${ }^{11}$ or undertaken by IMPEL ${ }^{12}$ ) have revealed or otherwise confirmed widely differing types and quality of environmental inspection systems across Member States. Differences are often marked in terms of resourcing, number of agencies involved as well as supervision strategies employed. Environmental inspection is a key element in the law enforcement toolbox, not least given its

\footnotetext{
${ }^{9}$ Treaty of Lisbon amending the Treaty on European Union and the Treaty establishing the European Community [2007] OJ C306/1.

${ }^{10}$ As composed of the TEU and TFEU, consolidated versions of which have been published in the EU Official Journal [2012] OJ C326/13-390. See also: http://eur-lex.europa.eu/collection/eu-law/treaties.html.

${ }^{11}$ See e.g. COWI/ECORYS/CE Impact assessment study into possible options for revising Recommendation 2001/331 providing for minimum criteria for environmental inspections - Final Report for the European Commission (2011) (ENV.G.1/FRA/2006/0073); IEEP/BIOIS/ECOLOGIC, Study on inspection requirements for waste shipments - Final Report for the European Commission (ENV G.4/FRA/2007/0067).

${ }^{12}$ See e.g. 2003 report of the IMPEL Secretariat Short overview of the organisation of inspection in the EU Member States, Norway and acceding and candidate countries. See also IMPEL reports on inspections regarding waste shipments: Seaport Projects I-II (2003-6), Verification of Waste Destinations Projects I (20036) and Enforcement Actions Projects I-III (2008-12). An overview is provided for on the IMPEL website at: http://impel.eu/cluster-2/
} 
preventative dimension in assisting in efforts to minimise instances of non-compliance arising.

Owing to political resistance and sensitivities on the part of several Member States, EU engagement in the subject of inspections proceeded rather tentatively initially. In a 1996 Communication on implementation of EU Law, ${ }^{13}$ the European Commission proposed that common guidelines be developed for national inspectorate systems. In response, the Council of the EU in a 1997 resolution ${ }^{14}$ invited the Commission to propose guidelines on the basis of work carried out by IMPEL. The decision to place IMPEL as a pivotal player in the construction of EU policy in this area meant, at least initially, that emergent common guidance would essentially lean towards an intergovernmental and consensual approach, one based on voluntary participation and non-binding recommendations. The work on common guidance ultimately culminated in the adoption of a non-binding instrument in 2001 as discussed below.

\subsection{Recommendation 2001/331 on Minimum Criteria for Environmental}

\section{Inspections (RMCEI)}

Under the aegis of the Union's Sixth Environment Action Programme ${ }^{15}$ (EAP6) (2001-2012) the EU adopted a non-binding soft law instrument on national environmental inspection systems, namely Recommendation $2001 / 331^{16}$ providing for minimum criteria for environmental inspections (RMCEI). The aim of the RMCEI, which is still in force, is to improve the level of effectiveness of Member State inspectorate systems for both environmental protection reasons as well as reasons concerned with distortion of competition ${ }^{17}$ within the single market. The material scope of the RMCEI is limited and focuses principally on the industrial emissions sector. It covers the activities of installations whose air emissions, water discharges or waste management activities are subject to

\footnotetext{
${ }^{13} \mathrm{COM}(96) 500$ Commission Communication Implementing Community Environmental Law, 22.10.1996. ${ }^{14}$ Council Resolution of 7 October 1997 on the drafting, implementation and enforcement of Community environmental law [1997] OJ C321/1.

${ }^{15}$ Decision 1600/2002 of the European Parliament and of the Council of 22 July 2002 laying down the Sixth Community Environment Action Programme [2002] OJ L242/1.

${ }^{16}$ Recommendation 2001/331 providing for minimum criteria of environmental inspections in the Member States [2001] OJ L118/41 (RMCEI). Recommendations are non-binding measures under EU law: see Art.288(5) TFEU.

${ }^{17}$ Namely, to ensure that market operators are subject to commensurate levels of scrutiny and accompanying costs for the purpose of EU environmental law compliance irrespective of their location within the Union.
} 
authorisation, permit or licensing requirements under EU law, ${ }^{18}$ namely integrated pollution prevention and control as now regulated primarily by the Industrial Emissions Directive 2010/75. ${ }^{19}$ The RMCEI stipulates that Member States should observe a range of minimum criteria regarding the planning of inspections, ${ }^{20}$ organisation of routine and non-routine site visits, ${ }^{21}$ investigations into suspected serious breaches, ${ }^{22}$ as well as filing reports on and evaluating next steps with respect to site visits. ${ }^{23}$ It constitutes an important milestone for EU policy on environmental inspections and establishes some core benchmarks for national inspectorate systems.

In 2007 the Commission undertook a review ${ }^{24}$ of the effectiveness of the RMCEI, a process foreseen in the instrument. ${ }^{25}$ A number of significant shortcomings were identified. Several Member States had failed to implement its requirements by the 2002 deadline set in the recommendation. ${ }^{26}$ The Commission reported that implementation of the instrument was unclear or partially complete in most Member States, with only five countries ${ }^{27}$ assessed as having reached a high level' of implementation. ${ }^{28}$ A notable shortcoming was the fact that the criteria identified in the RMCEI regarding inspection plan coverage had not been implemented in several Member States, so that many plans omitted to provide for strategic elements. The Commission also found that the material scope of the soft law instrument was too narrow, in having excluded a range of activities and sectors with significant impacts that were also subject to EU environmental legislative controls (such as the areas of wildlife hunting and trade, habitat conservation, chemical use and transboundary waste shipment). It also noted in the 2007 review that various terms in the RMCEI had been interpreted differently by Member States, which had led to significant divergence in national implementation strategies. For instance, it reported that some Member States considered the term 'inspection' meant only direct controls at installations, in contrast with the

\footnotetext{
${ }^{18}$ Paragraph II (1)(a) RMCEI.

19 Directive 2010/75 on industrial emissions (integrated pollution prevention and control) (recast) [2010] OJ L334/17 which has succeeded the earlier IPPC legislation, namely former IPPC Directive 96/61[1996] OJ L257/26 as previously consolidated by Directive 2008/1 [2008] L24/8.

${ }^{20}$ Paragraph IV RMCEI.

${ }^{21}$ Paragraph V RMCEI.

${ }^{22}$ Paragraph VII RMCEI.

${ }^{23}$ Paragraph VI RMCEI.

${ }^{24}$ SEC (2007)1493 Commission Report on implementation of Recommendation 2001/331 providing for minimum criteria for environmental inspections, 14.11.2007.

${ }^{25}$ Paragraph IX RMCEI.

${ }^{26}$ Paragraph X RMCEI.

${ }^{27}$ Belgium, Germany, Ireland, the Netherlands, Sweden and the UK.

${ }^{28}$ See p 20 of SEC (2007)1493, n.24 above.
} 
recommendation's broader conceptualisation of the term to include effectively any activity aiming to promote compliance of installations with EU environmental requirements. ${ }^{29}$ There was also some degree of confusion over the meaning of the undefined concept of 'inspection plan' contained in the RMCEI. Some Member States considered that a plan simply amounted to a list of installations to be inspected over time, as opposed to the Commission's and other Member States' understanding that this term should mean a strategic document drawn up for the purpose of determining inspection priorities. Information supplied by Member States to the Commission about their implementation of the RMCEI was not always comparable, making it difficult at times for the latter to assess the relative quality and effectiveness of Member States' implementation of the instrument. The Commission decided to aim for a revision of the RMCEI coupled with steps to introduce targeted binding minimum inspection standards through sectoral legislation. It was somewhat surprising that the Commission initially rejected the idea of using a legally binding instrument to succeed the RMCEI, given that it was reasonable to conclude that the poor state of implementation of the recommendation identified in the Commission's 2007 review was in substantial part due to its soft, non-binding legal status.

\subsection{Sectoral EU environmental legislation on inspections}

In parallel with the adoption of the general horizontal framework instrument of the RMCEI, the EU has steadily built up a range of sectoral legislative provisions in relation to minimum standards on environmental inspections carried out by national competent authorities. The following environmental sectors are now subject to minimum inspection obligations under EU legislation: industrial emissions, ${ }^{30}$ major accident hazards involving dangerous substances, ${ }^{31}$ waste management, ${ }^{32}$ ozone depleting substance management, ${ }^{33}$ geological storage of carbon, ${ }^{34}$ scientific experimentation on animals, ${ }^{35}$ the civil nuclear industry ${ }^{36}$ as well

\footnotetext{
${ }^{29}$ See Paragraph II.2 RMCEI.

${ }^{30}$ Directive 2010/75 on industrial emissions (integrated pollution prevention and control) (recast) [2010] OJ L334/17.

${ }^{31}$ Directive $2012 / 18$ on the control of major-accident hazards involving dangerous substances, amending and subsequently repealing Directive 96/82 [2012] OJ L197/1 ('Seveso III').

${ }^{32}$ Directive 2008/98 on waste and repealing certain Directives (OJ 2008 L312/3), Directive 1999/31 on the landfill of waste [1999] OJ L182/1, Directive 2006/21 on the management of waste from extractive industries and amending Directive 2004/35 [2006] OJ L102/15, Directive 2012/19 on waste electrical and electronic equipment (WEEE) (recast) [2012] OJ L197/38 and Regulation 660/2014 amending Regulation 1013/2006 on shipments of waste [2014] OJ L189/135.

${ }^{33}$ Regulation 1005/2009 on substances that deplete the ozone layer (recast) [2009] OJ L286/1.

${ }^{34}$ Directive 2009/31 on the geological storage of carbon dioxide and amending various Directives [2009] OJ L140/114.

${ }^{35}$ Directive $2010 / 63$ on the protection of animals used for scientific purposes [2010] OJ L276/33.
} 
as the common fisheries policy (CFP). ${ }^{37}$ The Union has also established some distinct audit and inspection control frameworks in relation to particular areas of EU climate policy, specifically in relation to the sectors concerning greenhouse gas (GHG) emissions trading as well as carbon dioxide $\left(\mathrm{CO}^{2}\right)$ emissions from shipping. These particular monitoring controls in the climate policy sector, underpinned by EU secondary legislation, do not centre or focus directly on national competent authority engagement in inspections and are accordingly considered separately at the end of this section.

The EU legislative provisions on environmental inspections carried out by national competent authorities vary in detail and stringency. This is partly a result of tailoring according to the perceived requirements for an individual sector and partly a result of timing. The earliest generation of instruments with provisions concerning inspections tended to contain relatively general and brief clauses on inspection standards, indicative of a preference on the part of the EU legislature to defer essentially to Member States over detailed operational requirements of national inspectorate systems. A notable example is EU's Waste Framework Directive, ${ }^{38}$ which contains but a few general provisions on inspection requirements. Its key stipulation on inspections is enshrined in Article 34(1), which requires Member States to subject waste operators to 'appropriate periodic inspections by the competent authorities'. In contrast, the most recent generation of EU environmental legislative instruments contain far more detailed inspection provisions, exemplified by the Industrial Emissions Directive, ${ }^{39}$ the Seveso III Directive ${ }^{40}$ and recent amendments introduced to the Waste Shipments Regulation. ${ }^{41}$ They flesh out and adapt the core stipulations of the RMCEI to the particular sectoral requirements at hand, and contain minimum standards with respect to inspection planning, inspection visits (routine and nonroutine), recording and reporting of inspections as well as inter-authority co-operation. ${ }^{42}$

\footnotetext{
${ }^{36}$ See Art.35 EAEC (Euratom Treaty) and Directive 2009/71/Euratom establishing a Community framework for the nuclear safety of nuclear installations [2009] OJ L172/18 as amended by Directive 2014/87/Euratom [2014] OJ L219/42.

${ }^{37}$ Regulation 768/2005 establishing a Community Fisheries Control Agency and amending Regulation 2847/93 [2005] OJ L347 in conjunction with Regulation 1224/2009 establishing a Community control system for ensuring compliance with the rules of the CFP [2009] OJ L343.

${ }^{38}$ Directive 2008/98 on waste and repealing certain directives [2008] L312/3. The 2008 directive does little to add to provisions on inspections contained in earlier versions of the Waste Framework Directive.

${ }^{39}$ Directive 2010/75, n.30 above.

${ }^{40}$ Directive 2012/18, n.31 above.

${ }^{41}$ Regulation 1013/2006 on shipments of waste [2006] OJ L190/1 as amended by Reg.660/2014 [2014] OJ L189/135.

${ }^{42}$ For further discussion on the latest generation of inspection provisions, see Ch11 of Hedemann-Robinson (2015) n.1 above.
} 
Table 1 below provides an overview of the variegation of spread of obligations on environmental inspection requirements contained current Union legislation.

\section{Table 1: EU environmental legislation on inspections by national authorities}

The pursuit of a 'sectoral track' approach to inspection regulation in the EU environmental policy sector has been justified principally on pragmatic grounds. Particular environmental sectors have been prioritised for EU legislative attention according to the perceived level of environmental risk of specific activities and in light of the overall record amongst Member States on implementation. This pragmatic and piecemeal approach to policy development has led to a great variation in terms of range, specificity and intensity of inspection obligations across sectors, sometimes difficult to justify. To take but one example, widely differing approaches exist amongst legislative instruments regarding updating inspection plans. The the EU's waste shipment rules require Member States, as from the beginning of 2017, to update inspection plans every three years. ${ }^{43}$ The inspection plans of installations covered by industrial emissions and major accident hazard controls regulations are subject to the looser, vaguer requirement of having to be 'regularly reviewed'. ${ }^{44}$ In other areas (waste management other than shipment, ozone depleting substances and animal experimentation) no specific inspection planning review requirements are stipulated. Whilst it might be argued that the sectoral approach has certain advantages (notably, by tailoring inspection standards according to particular identified needs of a regulated area), in practice this had led to a lack of coordination between sectors and to some inconsistency between the sectoral instruments. Notably, national (and sub-national) environmental inspectorate systems charged with overseeing the correct implementation of EU environmental law are confronted with complex technical and managerial challenges as they have to take on board the multiplicity of legislative instrumentation and diversity of obligations at Union level on inspection standards. An additional problem is presented by the significant gaps regarding the current material scope of EU environmental inspection standards legislation. Notably, the nature protection, water and air quality sectors have not yet been made subject to any specific minimum standards provision. Moreover, there are no binding requirements on minimum

\footnotetext{
${ }^{43}$ Art.50 (2a) Regulation 1013/2006 on shipments of waste as amended, n.41 above.

${ }^{44}$ See Art.23 (2) of Directive 2010/75, n.30 above, and Art.20(3) of Directive 2012/18, n.31 above.
} 
levels of resourcing for inspectorates ${ }^{45}$ and only a very few instruments foresee a role for EU level inspections. All these gaps and inconsistencies underline the shortcomings of overreliance on a sectoral track approach and identify a need for the EU to ensure that it has effective systems in place to ensure appropriate 'horizontal' co-ordination of inspections management across environmental sectors. As will be discussed in the next section, the Union has identified a need for improvement in this regard in its Seventh Environment Action Programme (2013-2020).

Brief mention must also be made of the distinct systems of audit control established by particular Union legislative instruments concerning EU climate policy, specifically in relation to GHG emissions trading and carbon emissions from maritime transport. In these areas the Union has developed control mechanisms that focus on actors other than national competent authorities that are directly engaged in inspection activity. Under the auspices of the EU's legislation on the Union's Emission Trading Scheme (ETS), ${ }^{46}$ implementation assurance of its 'cap and trade' scheme on greenhouse emissions of industrial installations rests principally upon two control 'pillars', namely oversight of monitoring and reporting by operators of emissions $^{47}$ as well as verification of GHG emission reports. ${ }^{48}$ The combined function of these control systems is to ensure that at the end of each year installations surrender a correct amount of emission allowances corresponding to their emission levels, so to ensure that the EU ETS system works effectively and is not subject to fraud or abuse. Under the first control pillar, national competent authorities are charged with the responsibility to check that operators have in place appropriate emission monitoring plans for the purpose of compiling accurate data on their GHG emissions. Under the second control pillar, Member States are to ensure that nationally accredited auditors (or 'verifiers') check to see that each installation's monitoring plan has been implemented correctly by the operator, a process that involves

\footnotetext{
${ }^{45}$ The Industrial Emissions Directive 2010/75, n.30 above, is one of the few pieces of sectoral legislation that broach the subject of resourcing of inspectorates, but does so in a weak fashion. Specifically, recital 26 of the preamble to the Industrial Emissions Directive 2010/75 exhorts Member States to 'ensure that sufficient staff are available with the skills and qualifications necessary to carry out [IED] inspections effectively'. The directive does not contain any specific binding requirements on the matter, though.

${ }^{46}$ The main framework instrument being Directive 2003/87 establishing a scheme for greenhouse gas emission allowance trading within the Community and amending Directive 96/61 [2003] OJ L275/32 as amended (most recently by Directive 2009/29 [ 2009] OJ L140/63) (Emissions Trading Directive or 'ETD').

${ }^{47}$ See Regulation $601 / 2012$ on the monitoring and reporting of greenhouse gas emissions pursuant to Directive 2003/87 [2012] OJ L181/30 as amended (most recently by Reg.743/2014 [2014] OJ L201/1).

${ }^{48}$ See Regulation 600/2012 on the verification of greenhouse gas emission reports and tonne-kilometre reports and the accreditation of verifiers pursuant to Directive 2003/87 [2012] OJ L181/1.
} 
sampling and site visit inspection. ${ }^{49}$ Verification is important for the operator, for without it the latter is barred from engaging in future emissions allowance trading and is also liable for payment of an excess emissions penalty if found to have failed to surrender a sufficient number of emission allowances. ${ }^{50}$ In practice, inspections are carried out by private undertakings acting as verifiers, ${ }^{51}$ authorised under the aegis of a national accreditation framework, ${ }^{52}$ whose verification reports are subject to a system of prior independent review. ${ }^{53}$ National competent authority work focuses essentially on the upstream control work of scrutinising the propriety of operators' emission monitoring plans. Recently, the EU has also adopted legislation concerning auditing of GHG emissions from the maritime transport sector which is in broad alignment with the approach taken in respect of emissions trading. EU Regulation $2015 / 757^{54}$ requires operators of ships over 5,000 gross tonnage using EU ports to ensure that, with effect from January 2018, their monitoring and reporting of $\mathrm{CO}^{2}$ emissions is subject to independent auditing from accredited verifiers, who may undertake spot-checks to determine the reliability of operator reports. ${ }^{55}$

\subsection{Impact of the EU's Seventh Environment Action Programme (EAP7)}

With the adoption of its Seventh Environment Action Programme (EAP7) (2013-2020) ${ }^{56}$ the EU's position on the issue of environmental inspections has evolved to become far more resolute and ambitious. Notably, an express commitment is enshrined within EAP7 on extending binding criteria on minimum inspection standards as well as the promotion of support capacity at EU level. This assurance followed an earlier 2012 Commission Communication $^{57}$ concerning ways and means of enhancing delivery of Union environmental measures, in which the Commission signalled its intention to push for Union legislative

\footnotetext{
${ }^{49}$ See Arts.20-21 of Reg.600/2012, n.48 above.

${ }^{50}$ See Arts. $15-16$ of ETS Directive 2003/87, n.46 above.

${ }^{51}$ The EU legislation does not specifically rule out the possibility of officials of national competent authorities acting as verifiers where appropriately qualified, but it is unlikely that in practice authorities would have the requisite staff resources to do this. For comments on the use of private verifiers, see M. Peeters, 'The Enforcement of Greenhouse Gas Emissions Trading in Europe: Reliability Ensured?' in L. Paddock et al (eds.) Compliance and Enforcement in Environmental Law: Toward More Effective Implementation (Edward Elgar, 2011) at pp417-418.

${ }^{52}$ See Chs IV-V of Reg.600/2012 (supra n78). The system of accreditation is developed out of the one used for accreditation for marketing of products under Regulation 765/2008 (OJ 2008 L218/30).

${ }^{53}$ Art.25 of Reg.600/2012, n.48 above.

${ }^{54}$ Regulation $2015 / 757$ on the monitoring, reporting and verification of carbon dioxide emissions from maritime transport, and amending Directive 2009/16 [2015] OJ L123/55).

${ }^{55}$ See esp. Art. 15 of Reg.2015/757, n.54 above.

${ }^{56}$ Decision 1386/2013 on a General Union Environment Action Programme to 2020 - Living well, within the limits of our planet, $\mathrm{n} .8$ above.

${ }^{57}$ COM (2012)95 final, Commission Communication Improving the delivery of benefits from EU environmental measures: building confidence through better knowledge and responsiveness, 7.3.2012.
} 
approval broadening and upgrading the existing EU framework on inspections and surveillance. ${ }^{58}$ The EU's recent drive to expand its work in the area of environmental inspections is enshrined within one of nine priority objectives of EAP7, namely Priority Objective $4^{59}$ concerning implementation. Within Priority Objective 4 inspections and surveillance co-exist with three other implementation matters that the Union wishes to enhance. ${ }^{60}$ The principal provision regarding the development of existing EU policy regarding inspections and surveillance is contained in paragraph 65(iii) of the Annex to the Decision adopting the EAP7, which stipulates that the Union's environment policy programme requires:

'extending binding criteria for effective Member State inspections and surveillance to the wider body of Union environmental law, and further developing inspection support capacity at Union level, drawing on existing structures, backed up by support for networks of professionals such as IMPEL, and by the reinforcement of peer reviews and best practice sharing, with a view to increasing the efficiency and effectiveness of inspections'.

This EAP7 provision accordingly committed to bolster the EU engagement in the area of environmental inspections along two dimensions: by enhancing the inspection systems of national competent authorities and also through the complementary development of inspection capability at EU institutional level. Both dimensions will be considered briefly below. To date, the Commission has only begun to focus in earnest on the first of the two dimensions, namely at the level of national inspectorates.

\subsection{National environmental inspections and EAP7}

Until very recently, the European Commission's services within its Environment DirectorateGeneral (DG ENV) were actively working on a proposal for a general horizontal EU directive on national environmental inspection standards. This work followed a 2011 impact

\footnotetext{
${ }^{58}$ See pp 7-8 of COM (2012)95, n.57 above.

${ }^{59}$ Priority Objective 4 (To maximise the benefits of Union environmental legislation by improving implementation) of the Annex to Dec.1386/2013, n.8 above.

${ }^{60}$ The three other matters concern improvements to: information collection and dissemination on the state of implementation, national systems handling environmental complaints as well as access to environmental justice (in accordance with the Århus Convention and Union law). (See paras.58-65(a)-(e) of the Annex to Dec.1386/2013, n.8 above).
} 
assessment study considering options for revision of the $\mathrm{RMCEI}^{61}$ as well as a stakeholder consultation which delivered strong support for strengthening the existing EU legal framework. ${ }^{62}$ The Commission held a number of stakeholder meetings, including expert workshops, which revealed some broad contours of the initial thinking of its internal services (i.e. within the DG ENV). These indicate that the Commission services within DG ENV are minded to recommend a prospective horizontal framework directive to promote coherence within existing EU legislation on environmental inspections. ${ }^{63}$ The initiative would be legally binding, in contrast to the RMCEI. It would cover the broad span of EU existing environmental legislation, some 40 measures concerning the water, industrial emissions, major accident hazards, air, waste, chemicals, nature and biodiversity sectors as well as certain cross-cutting aspects. ${ }^{64}$ The draft legislative initiative envisaged by DG ENV would be based on a compliance assurance approach, which entails Member States utilising risk assessment for the purposes of identifying strategically principal non-compliance problems, before applying various risk mitigation techniques (compliance promotion, monitoring and enforcement) in order to enhance levels of adherence to EU environmental legislation. Specifically, it would oblige Member States to fulfil a range of duties beyond those in the RMCEI including undertaking the following steps in a compliance assurance chain:

- Risk assessment (Stage 1): Each Member State to undertake a strategic risk assessment of non-compliance within their respective territories, reviewable every 4 years. The strategic assessment would serve inter alia to identify sectors with notable compliance issues and accordingly warrant greater inspection prioritisation. This would be accompanied operationally by national surveillance and inspection plans along the lines of the RMCEI model as developed by the IED and Seveso III

\footnotetext{
${ }^{61} \mathrm{COWI} / \mathrm{ECORYS/CE} \mathrm{Impact} \mathrm{assessment} \mathrm{study} \mathrm{into} \mathrm{possible} \mathrm{options} \mathrm{for} \mathrm{revising} \mathrm{Recommendation} \mathrm{2001/331}$ providing for minimum criteria for environmental inspections - Final Report for the European Commission (2011) (ENV.G.1/FRA/2006/0073). Available for inspection on the Commission's DG ENV website at: http://ec.europa.eu/environment/legal/law/inspections.htm

${ }^{62}$ The details of the stakeholder consultation process and findings are available for inspection on the Commission's DG ENV website at: http://ec.europa.eu/environment/legal/law/inspections.htm

${ }^{63}$ These observations are based upon an Outline Paper and Explanatory Paper presented by the European Commission's DG ENV at a joint workshop between the Commission and IMPEL in Rome in December 2014. The papers presented to the workshop area available for inspection at: http://ec.europa.eu/environment/legal/law/inspections.htm.

${ }^{64}$ Specifically, matters covered by Directive 2004/35 on environmental liability with regard to the prevention and remedying of environmental damage [2004] OJ L143/56 (Environmental Liability Directive), Directive 2007/2 establishing an Infrastructure for Spatial Information in the EC [2007] OJ L108/1 (INSPIRE Directive) and Directive 2011/92 on the assessment of the effects of certain public and private projects on the environment [2012] OJ L26/1 (Environmental Impact Assessment or EIA Directive) as amended. The DG ENV Outline Paper contains an Annex listing the EU environmental legislation to be covered by the prospective EU framework inspections instrument.
} 
Directive, reviewable every two years. Such plans would incorporate a risk assessment approach, include appropriate levels of routine and non-routine inspections as well as develop effective inter-agency coordination. In particular, national plans would be crafted in light of the results of the overall strategic assessment, which would appraise the relative state of non-compliance concerning EU environmental protection rules.

- Risk mitigation (Stage 2): EU Member States would take steps to mitigate against the non-compliance risks identified at the initial risk assessment stage by deploying three core tools or techniques, namely: compliance promotion, compliance monitoring (via surveillance, inspections and investigations) as well as enforcement. ${ }^{65}$ The overall approach to risk mitigation would be to encourage Member States to consider deployment of the most effective risk mitigation technique suitable to the particular non-compliance scenario, bearing in mind that recourse to softer compliance promotion initiatives (such as the provision of advice and assistance or securing undertakings from operators) may well be more effective in practice in the long term to attaining better levels of implementation amongst operators other than persistent or intentional serious offenders. In terms of recourse to enforcement, national authorities would be encouraged to consider using one or more sanctions (informal or formal, light or heavy) in proportion to the incident of detected non-compliance with EU environmental rules. The Commission's thinking here resonates strongly with the United Kingdom (UK) approach with respect to supervisory operations of regulatory authorities. Other key aspects of risk mitigation signalled in the Commission's outline documentation include requiring Member States to ensure that follow-up strategies are consistently drawn up for cases of detected non-compliance as well as that reporting and transparency underpins inspection and surveillance activities of national authorities.

The Commission has made considerable headway with the proposal, yet it may still be some way off from being ready to recommend the launch of a formal draft initiative. There may well be further need for informal discussion with stakeholders. Moreover, the DG ENV draft does not (yet) contain provisions to ensure that Member State implementation of the

${ }^{65}$ The DG ENV Explanatory Paper refers to these tools/techniques as being the 'three pillars' of risk mitigation. 
instrument is subject to sufficiently rigorous review and that the issue of adequate Member State resourcing of inspection systems is appropriately addressed.

As far as review is concerned, a number of requirements could be integrated within the draft legislative text which would serve as useful checks to monitor Member State compliance with the prospective EU environmental inspection instrument. As a minimum the draft instrument should incorporate the existing review provisions contained in the RMCEI, namely Member State duties to report on implementation experience to the European Commission in conjunction with provision for a periodic Commission review as to whether legislative amendments or additions need to be made to the EU measure. The inclusion of Member State reporting obligations to the Commission on the state of and experience gleaned from implementing the EU instrument's requirements are particularly important, given the current paucity of reliable data and information on national inspection systems provided to date under the aegis of the RMCEI and relevant sectoral EU environmental legislation. The non-binding status of the RMCEI no doubt contributed to the poor quality of implementation feedback provided by Member States, whilst the various provisions on inspection requirements contained within EU environmental legislation have not typically been made the subject of a robust implementation review process. Review procedures in a successor instrument to the RMCEI could be usefully supplemented with the inclusion of a Member State duty to undergo periodic independent auditing of their inspection regimes to appraise effectiveness of delivery of EU requirements. Independent auditing could be conducted by a range of actors, such as a private environmental consultancy, national audit authority, IMPEL or the European Commission. Arguably, IMPEL would be a strong candidate to assume such a role, given its technical expertise (its membership drawn from national environmental authorities), wealth of accumulated information on Member State inspectorate structures as well as long-standing experience in voluntary auditing of Member State environmental authorities. Other flanking review mechanisms could conceivably be used, such as conferral of implementing powers to the Commission under the aegis of the 'comitology' process ${ }^{66}$ although this might well be resisted by Member States as an overly centralising move.

The issue of adequate resourcing of national inspectorates is an important one which lies at the heart of achieving an effective environmental monitoring system. At first glance, it might

\footnotetext{
${ }^{66}$ See Art.291 (2)-(4) TFEU and Regulation 182/2011 laying down the rules and general principles concerning mechanisms for control by Member States of the Commission's exercise of implementing powers [2011] OJ L155/13. Post-Lisbon, 'comitology' envisages the conferral of powers of implementation on the Commission in legally binding Union acts, where uniform conditions for the latters' implementation are needed.
} 
seem logical to expect that a general EU instrument on inspections should incorporate minimum standards on resourcing aspects (including notably quantitative and qualitative aspects of personnel, training and equipment). However, for political, administrativetechnical and legal reasons the European Commission has little room for manoeuvre. From a political perspective, the issue of administrative resourcing is highly sensitive, not least since it directly impinges upon national budgetary decisions concerning financing of public services. The Council of the EU too is likely to have significant concerns about loss of national administrative autonomy if any Commission proposal seeks to introduce clauses on common minimum resourcing requirements. Secondly, it has proven problematic technically to establish agreement between environmental authorities within IMPEL over the use of resourcing benchmarks (notably regarding personnel numbers) as a common performance indicator criteria. ${ }^{67}$ Thirdly, from a legal perspective, in the wake of amendments introduced by the Lisbon Treaty the EU treaty framework excludes generally the possibility of the Union adopting harmonising measures concerning improvements to national administrative 'capacity' ${ }^{68}$ The latter aspect is considered in more detail in Section 3 below.

Accordingly, it is not that surprising to find that most existing EU environmental inspection rules essentially side-step the subject of resourcing levels of inspectorates. On the very few occasions that the issue of administrative resourcing has been incorporated within EU environmental legislative instrumentation, it has only been done in very general ${ }^{69}$ or exhortatory ${ }^{70}$ terms, thereby essentially deferring key decisions to Member States. However, this does not mean that the Commission should have to drop the issue of resourcing entirely from a draft general EU environmental inspections instrument, far from it. It does not need to remain the elephant in the room. Notably, it would be most useful if the draft legislative instrument were to include provision requiring Member States to be transparent about the

\footnotetext{
${ }^{67}$ See e.g. IMPEL Project Report 2009/03 Developing performance indicators for environmental inspection systems (April 2010), esp. discussion on inspector numbers at pp8-9.

${ }^{68}$ See Art.197 (2) TFEU.

${ }^{69}$ See Art.50(2a)(f) and (g) of Reg.1013/2006 on waste shipments as amended by Reg.660/2014, n.41 above, which requires Member States by 1.1.2017 to ensure that their waste shipment inspection plans include information on 'the training of inspectors on matters relating to inspections' and 'the human, financial and other resources for that plan'. See also Art.5(2)(c) of Directive 2009/71/Euratom establishing a Community framework for the nuclear safety of nuclear installations as amended, 36 above, which requires that the competent national regulatory authority 'is given dedicated and appropriate budget allocations to allow for the delivery of its regulatory tasks as defined in the national framework'.

${ }^{70}$ See recital 26 of the preamble to the Industrial Emissions Directive 2010/75, n.30 above, which states that 'Member States should ensure that sufficient staff are available with the skills and qualifications needed to carry out those inspections effectively'. See also recital 26 to the Seveso III Directive 2012/18, n.31 above, which additionally states that 'competent authorities should provide appropriate support using tools and mechanisms for exchanging experience and consolidating knowledge including at Union level.'
} 
level of resources they invest in their inspectorate systems, with an obligation to report resource data regularly to the Commission. Such an obligation would enable the Commission to make publicly available a comparative report on Member State resourcing of their inspectorates. Such transparency would assist in shining a light on weak spots in national inspection systems as well as placing soft, indirect pressure on Member States to take remedial action, as appropriate. Moreover, a general provision requiring Member States to ensure that their inspection systems are effective in assisting Member States in the fulfilment of their implementation responsibilities could serve as a useful, albeit indirect, legal guarantee against manifestly deficient inspection systems. Specifically, where the level of investment by a Member State in its inspection system is clearly incapable of delivering effective compliance monitoring of EU environmental legislative requirements, the Commission could use this evidence in support of an infringement case under Articles 258/260 TFEU on the basis of non-compliance with the effectiveness requirement. Arguably, such a clause might receive sufficient support from all sides. From the perspective of most Member States, it would be likely to assuage concerns about undue supranational intrusion into the sphere of national administrative autonomy. At the same time, such a clause would have some teeth in upholding the collective Union interest in ensuring effective application of EU law, which is attractive from the Commission's perspective.

Notwithstanding DG ENV's substantial interest and engagement invested in a successor initiative to the RMCEI, it is not clear when (or indeed if) the current college of Commissioners will be receptive to the adoption of a formal legislative proposal for a directive to replace the 2001 recommendation. Enhancing the implementation of EU environmental law, including the issues of environmental inspections and access to environmental justice identified in EAP7, does not feature among the list of priorities identified in the Commission President's published mission letter ${ }^{71}$ of November 2014 to Karmenu Vella, Commissioner for Environment, Maritime Affairs and Fisheries, for his five year tenure. The new administrative structure within the Commission organised by the President also makes it difficult for a fresh legislative initiative to emerge. Notably, for any new legislative proposal to be included within the Commission's annual work programme, ${ }^{72}$ one of the Commission Vice-Presidents must first recommend it on the basis that it seemingly

\footnotetext{
${ }^{71}$ Available for inspection at: http://ec.europa.eu/commission/2014-2019/vella en.

72 The Commission's Work Programme for 2015 is set out in COM (2014)910 Commission Communication Commission Work Programme 2015 - A New Start, 16.12.2014. Available for inspection at: http://ec.europa.eu/atwork/key-documents/index_en.htm.
} 
fits within the 2014 Political Guidelines presented by the Commission President to the European Parliament. ${ }^{73}$ Given that environmental policy, other than in respect to climate change, barely features amongst the ten priorities of the President's Political Guidelines, ${ }^{74}$ it may well prove a tough task for DG ENV to persuade the Commission hierarchy to adopt a legislative proposal on environmental inspections. The strongest argument in favour of a new initiative to replace the RMCEI is the fact that the EU has specifically endorsed such a move under the auspices of EAP7, which is underpinned by a legally binding Union decision. Time will tell how these factors will play out politically. However, informal feedback from within the Commission's services suggests that a formal endorsement of any initiative is unlikely to be forthcoming soon. The Commission's Work Programme for 2015 did not include amongst its list of Commission initiatives for the initial calendar year of the new Commission college a proposal on environmental inspections. This suggests, perhaps rather ominously, that the Commission 'will not present proposals that do not contribute to [the] priorities' of the Political Guidelines', 'will apply [the practice of] political discontinuity" ${ }^{75}$ and "will take off the table pending proposals that do not match our objectives or which are going nowhere' ${ }^{76}$

\subsection{Environmental inspections at EU institutional level and EAP7}

For several years a debate has rumbled on over whether environmental inspection capacity at EU institutional level should be developed. On the one hand, the European Parliament has registered its approval of the establishment of an EU-level inspectorate capability on a number of occasions. ${ }^{77}$ On the other hand, EU Member States have traditionally been

\footnotetext{
${ }^{73}$ Junker J-C, A New Start for Europe: My Agenda for Jobs, Growth, Fairness and Democratic Change: Political Guidelines for the next European Commission (July 2014). Available for inspection at: http://ec.europa.eu/priorities/docs/pg_en.pdf

${ }^{74}$ The Political Guidelines identify 10 priority policy areas for the Commission college appointed for the period 2015-2020, which in broad terms may be highlighted as: jobs, growth and investment; digitalisation of the single market; energy union in conjunction with climate change policy; strengthening of internal market; deepening of economic and monetary union; attainment of a free trade agreement with the US; deepening the area of justice in conjunction with fundamental rights; development of a new migration policy; strengthening of Union external relations and strengthening of democratic structures of EU decision-making.

${ }^{75}$ In accordance with point 39 subpara. 2 of the Framework Inter-institutional Agreement on Relations between the European Parliament and Commission [2010] OJ L304/47 which stipulates that:

"The Commission shall proceed with a review of all pending proposals at the beginning of the

Commission's term of office, in order to politically confirm or withdraw them, taking due account of the view expressed by Parliament."

${ }^{76}$ COM (2014)910final, Commission Work Programme 2015: A New Start, 16.12.2004.

${ }^{77}$ See notably the 2008 EP Resolution on the review of Recommendation 2001/331(P6_TA(2008)0568) of 10.10.2008 (at para. 5) and 1999 EP Resolution on the proposal for a Council Recommendation providing for
} 
generally sceptical or resistant to the idea of endowing EU institutions with inspection powers in the environmental sector. Suggestions in the early 1990s to invest the European Environment Agency (EEA) with inspection powers were shot down by Member States. ${ }^{78}$ Whilst the EU legislation setting up the EEA specifically refers to the possible development of supervisory functions being assigned to the Agency at a later date, ${ }^{79}$ the Commission did not take up this issue in subsequent years when submitting amendments to the EEA's statutes. ${ }^{80}$ In 1997, the Council reaffirmed its clear disapproval of the establishment of a system of centrally and supranationally organised system of European environmental inspectors. ${ }^{81}$ The resistance to development of a supranational dimension to environmental inspections was also reiterated within the preamble of the RMCEI. ${ }^{82}$ Historically, Member States have resisted moves to establish a strong centralized inspection regime at Union level akin to that set up in other federal systems, such as the US. ${ }^{83}$

More recently however, the EAP7 has revived political interest in this area, signalling potentially a more open-minded approach to the idea of EU institutional involvement in inspections. Paragraph 65(iii) of the Annex to the EAP7 Decision ${ }^{84}$ stipulates that the Union's environment policy programme requires 'further developing inspection support capacity at Union level, drawing on existing structures'. DG ENV has indicated its interest in this area, having commissioned a study, which was published in 2013, on examining options for strengthening the EU level role in environmental inspections and strengthening the Commission's capacity to undertake effective investigations into alleged breaches in EU environmental law. ${ }^{85}$ The study identified three options potentially available to develop the Commission's role in inspections, namely: (1) conferral of audit powers to the Commission

minimum criteria for environmental inspections in the Member States of 26.4.1999 (PE.229.97/fin A4-0251/99) especially point B.2 of Explanatory Statement.

${ }^{78}$ Macrory has pointed out, though, that the UK government at the time appeared initially open to consider an auditing role for the Agency. See R. Macrory R, 'The Enforcement of Community environmental law: some critical issues' (1992) 29 Common Market Law Review 347.

${ }^{79}$ See Art.20 of Regulation 1210/90 on the establishment of the European Environment Agency and the European environment information and observation network [1990 OJ L120/1, as amended by Regulation 93/1999 [1999] OJ L117/1.

${ }^{80}$ As published in the Official Journal of the EU [1997] OJ C255/9 and [1998] OJ C123/6.

${ }^{81}$ [1997] OJ C321/1.

${ }^{82}$ See recital 5 to the preamble of the 2001 RMCEI, n.16 above.

${ }^{83}$ See e.g. E. Hall, 'Environmental Law in the EU: New Approach for Enforcement' (2007) Tulane Environmental Law Journal pp 277-303 at 294-5. See also n.114 below.

${ }^{84}$ Decision 1386/2013, n.8 above.

${ }^{85}$ BIO Intelligence Service/EcoLogic/IEEP, Study on possible options for strengthening the EU level role in environmental inspections and strengthening the Commission's capacity to undertake effective investigations of alleged breaches in EU environmental law - Final Report, 14.1.2013. Available for inspection at: http://ec.europa.eu/environment/legal/law/inspections.htm. 
to oversee national inspectorate systems; (2) conferral of inspection powers to the Commission and (3) an enhanced peer review approach to inspections based on IMPEL's approach with potentially enhanced Commission oversight.

A particularly interesting feature of the study was that it underlined that the European Commission already has acquired a range of audit and inspection powers in some environmental policy areas. Specifically, such powers are conferred by EU legislation in the following environmental sectors: ozone depleting substances, ${ }^{86}$ the common fisheries policy (CFP), ${ }^{87}$ civil nuclear energy ${ }^{88}$ and scientific experimentation on animals. ${ }^{89}$ Under the Ozone Depleting Substances Regulation (ODSR), ${ }^{90}$ the Commission may request national authorities to carry out investigations which may conceivably involve Commission participation. Yet direct involvement of Commission officials in ODS inspections is essentially theoretical and very rarely undertaken, not least given the limited number of staff available within DG ENV and the latter's recognition of superior knowledge of ODS sites held by national authorities. ${ }^{91}$ The Commission also has the right to obtain all necessary information from Member States, competent authorities and undertakings. ${ }^{92}$ The CFP regime endows the Commission with a stronger and more established inspection role. The EU Fisheries Control Agency is entrusted with responsibility to coordinate fisheries control and inspections by national authorities for the purposes of supervising implementation of CFP rules. ${ }^{93}$ In addition, EU level inspectors (Commission officials) have powers to undertake verification and inspections of fishing vessels and premises of entities engaged in CFP activities. ${ }^{94}$ Under the aegis of the EU's Animal Experimentation Directive, ${ }^{95}$ the Commission is vested with an auditing (as opposed to an inspection) role. It has power to conduct audits of national control systems in relation to animal experimentation where there is due reason for concern that those systems are not functioning sufficiently effectively. In the civil nuclear energy sector, EU law invests Commission with auditing and inspection tasks in relation to civil nuclear installations for the

\footnotetext{
${ }^{86}$ Regulation $1005 / 2009$ on substances that deplete the ozone layer (recast), n.33 above.

${ }^{87}$ See Regulation 768/2005 establishing a Community Fisheries Agency and Regulation 1224/09 establishing a Community control system for ensuring compliance with the rules of the common fisheries policy, n.37 above.

${ }^{88}$ Art.35 European Atomic Energy Community (EAEC) Treaty.

${ }^{89}$ Directive 2010/63 on the protection of animals used for scientific purposes [2010] OJ L276/33.

${ }^{90}$ Regulation 1005/2009, n.33 above.

${ }^{91}$ As indicated in the Study by BIO Intelligence Service/EcoLogic/IEEP (op cit.n94).

${ }^{92}$ See Art.28 of Reg.1005/2009, n.33 above.

${ }^{93}$ See Reg.768/2005 n.37 above.

${ }^{94}$ See Art.97 of Reg.1224/2009, n.37 above.

95 Directive 2010/63, n.89 above.
} 
purpose of radioactivity monitoring. ${ }^{96}$ For several years, the Commission has organised periodic site inspections in order to verify compliance with EU safety requirements in this sector. ${ }^{97}$

It is also evident that the Commission is vested with a number of well-established inspection powers in non-environmental sectors. Notable examples include Commission controls in the EU policy domains relating to food and veterinary safety ${ }^{98}$ as well as competition. ${ }^{99}$ The Union's Food and Veterinary Office (FVO) based within the Commission's Health and Food Safety Directorate General (DG SANTE) ${ }^{100}$ has a range of supervisory controls to oversee appropriate implementation and enforcement of EU rules on food safety, animal health, animal welfare, plant health and medical devices. Established in the wake of the BSE crisis in the late 1990s, its principal role is to carry out audit checks on behalf of the Commission to appraise the effectiveness of Member State authority control and compliance systems.

Auditing intensity is calibrated upon a risk assessment analysis of national control systems. In addition, the FVO may carry out inspections of national authorities where specific problems have been identified or where otherwise specifically required. The FVO carries out some 150 audits annually, with some 170 staff. The FVO audit-inspection model was considered as a potential model in the 2013 study commissioned by DG ENV to assess options for strengthening the EU level role in environmental inspections. ${ }^{101}$ The Commission had a strong inspection and sanctioning role in relation to the policing of EU competition policy for several years dating back to the early 1960 s. ${ }^{102}$ Since 2003 , EU legislation ${ }^{103}$ has vested the Commission as well as national competition authorities with joint powers for the purposes of supervising the application of EU competition rules to combat anti-competitive agreements

\footnotetext{
96 See Art.35 EAEC.

${ }^{97}$ See European Commission report covering the period 2008-2012: SWD (2013)226 Commission Staff Working Document On the application of Article 35 of the Euratom Treaty: Verification of the operation and efficiency of facilities for continuous monitoring of the levels of radioactivity in the air, water and soil, 18.6.2013.

${ }^{98}$ Regulation $882 / 2004$ on official controls performed to ensure the verification of compliance with feed and food law, animal health and animal welfare rules [2004] OJ L165/1, as amended.

${ }^{99}$ Regulation $1 / 2003$ on the implementation of the rules on competition laid down in Articles 81 and 82 of the Treaty [2003] OJ L1/1 as amended and Regulation 139/2004 on the control of concentrations between undertakings [2004] OJ L24/1.

${ }^{100}$ For information on the FVO see: http://ec.europa.eu/food/food veterinary office/index en.htm

${ }^{101}$ Study by BIO Intelligence Service/EcoLogic/IEEP, op cit.n94.

${ }^{102}$ See former Regulation 17/62 First Regulation implementing Articles 85 and 86 of the [former EEC] Treaty [1962] OJ L13/204. For information on the Commission's investigatory role in EU competition policy see the Commission's Competition Directorate-General's website (DG COMP) at: http://ec.europa.eu/competition/antitrust/procedures_101_en.html

${ }^{103}$ See Regulation 1/2003, n.99 above.
} 
and abuse of dominance. ${ }^{104}$ The Commission has a range of significant powers in this field, including the power to request information, arrange unannounced investigations of business premises, seize equipment and records, and take witness statements. ${ }^{105}$ Failures by corporations to comply with an investigation may attract significant financial penalties imposed by the Commission. ${ }^{106}$

To date, the European Commission has not signalled that it is likely to come forward with any new general initiative concerning inspections powers to be held at EU institutional level. Its relatively recent interest in exploring this area further, as reflected in the 2013 study commissioned by DG ENV as well as the reference to development of inspection support capacity at EU level in EAP7, ${ }^{107}$ appears to have cooled within the context of the tenure of the current Commission College (2014-2019). This is regrettable, given that an initiative to vest powers of investigation and auditing at supranational level in order to enhance the level of implementation of Union law would be beneficial. It would serve to strengthen the operation of the infringement procedure under Article 258 TFEU in relation to the appraisal of bad application cases and provide a framework for conducting more effective monitoring of the effectiveness of national authority environmental inspection systems.

\section{ENVIRONMENTAL INSPECTION REGULATION AND THE EU ADMINISTRATIVE LEGAL CONTEXT}

In addition to the initial cool reaction of the current Commission college towards EU- level action on inspections, it appears that other challenges lie in the way of Union policy development. Certain political and legal hurdles need yet to be overcome in order for the EU to be able to identify with adequate precision how a supranational inspection framework could be appropriately accommodated within the administrative architecture that services EU environmental policy. Notably, the EU legislature would have to ensure that it does not overstep the boundaries of policy competence set for the Union and thereby encroach unlawfully on matters reserved for Member State action. This is not as easy as one might

\footnotetext{
${ }^{104}$ For a general overview of the operation of the joint supervisory arrangements (collectively the EU Competition Network) see COM(2014) 453, Commission Communication Ten Years of Antitrust Enforcement under Regulation 1/2003: Achievements and Future Perspectives, 9.7.2014.

${ }^{105}$ See Arts.18-21 of Reg.1/2003, n.99 above.

${ }^{106}$ See Arts.23-24, ibid.

${ }^{107}$ Para. 65(iii) of the Annex to Dec.1386/2013, n.8 above.
} 
think, notwithstanding the 2007 Lisbon Treaty, which had as a principal objective to introduce amendments to the Union's foundational treaty framework so as to provide clarity on the extent of EU competence.

Before considering specifically the issue of legal competence, it is worth considering in more general terms the broader context of the division of roles between Union institutions and Member State authorities regarding the delivery of EU policy decisions within what has been termed as an emerging European 'composite' or 'integrated' administrative space. ${ }^{108}$ As is commonly recognised, the division of labour between Union institutions and national authorities concerning implementation of EU policy varies greatly across sectors. In areas such as competition policy, the Commission has historically (if no longer necessarily effectively) a leading role in administering EU law (so-called 'centralised' or 'direct administration'). In other common policy areas such as in the Common Agricultural Policy or EU Structural Funds, the Commission has administered Union policy jointly with national authorities ('shared administration'). Alternatively, as in the case of Union environmental policy and most EU common policy matters, the task of implementation has largely been shouldered by Member States, with a largely indirect role for the Commission in overseeing due implementation of EU legal requirements via mechanisms such as the infringement procedure ('indirect administration' or 'executive federalism, 109 ). This traditional triadic description of the balance of implementation responsibilities may now be criticised for being overstated, ${ }^{110}$ in the sense that the balance of responsibilities between Union and Member States over implementation is now mostly shared ${ }^{111}$ but with varying degrees of intensity of supranational and national authority involvement based on hierarchical as well as heterarchical relationships. ${ }^{112}$ The characteristic sharing of administrative responsibilities between Union and Member State institutional levels with respect to the delivery of EU policy is also reflected more generally in the multi-level constitutional system of governance

\footnotetext{
${ }^{108}$ See e.g. J. Reichel, 'Communicating with the European Composite Administration' (2014) 15 German Law Journal pp883-906 at 886 and H. Hofmann \& A.Türk, 'The Development of Integrated Administration in the EU and its Consequences' (2007) 13(2) European Law Journal pp253-271 at 253-255.

${ }^{109}$ See e.g. R. Schütze, European Union Law (Cambridge, 2015) at p334.

${ }^{110}$ See C. Harlow, 'Three Phases in the Evolution of EU Administrative Law', in P. Craig \& G. De Burca (eds.) The Evolution of EU Law 2nd Ed. (OUP, 2011) at p443.

${ }^{111}$ See e.g. P. Craig, EU Administrative Law $2^{\text {nd }}$ ed (OUP, 2012) at p27 et seq.

${ }^{112}$ See e.g. E. Heidbreder, 'Structuring the European administrative space: policy instruments of multi-level administration' (2011) 18(5) Journal of European Public Policy pp709-727 at 709-710 and H. Hofmann \& A.Türk A, n.108 above at p263.
} 
within the EU legal order. ${ }^{113}$ Nevertheless, the triadic model remains a useful starting point to appraise the state of administrative responsibilities in relation to EU environmental policy.

Notwithstanding some changes over time, it is fair to depict EU environmental policy as heavily reliant upon Member States for implementation at national level. ${ }^{114}$ Admittedly, since the EU's formal establishment of a common environmental policy in the mid-1980s under the aegis of the Single European Act (SEA) 1986 there has been an increased degree of organisational involvement at the European level in matters closely or directly relating to implementation, such as through the European Environment Agency (EEA) in environmental data-gathering, through IMPEL's facilitation of better implementation practice as well as inspections by the European Commission services in a limited number of environmental policy matters. However, in substance these developments have not served to change the predominant involvement of Member State authorities in ensuring delivery of EU environmental policy on the ground. The administrative architecture underpinning the delivery of EU environmental policy remains an example of 'indirect administration'. This is not that surprising for both political as well as pragmatic reasons. From a political perspective, it has been evident that a majority of EU Member States have remained sceptical regarding the idea of direct supranational institutional supervision in the delivery of Union policy at local level outside areas perceived to be most directly connected with transnational commercial aspects of the internal market (e.g. competition, banking) or disbursement of EU funds. ${ }^{115}$ From a pragmatic perspective, it has always been apparent that any direct involvement of the Commission (or other EU agency) in implementation supervision would be necessarily relatively limited owing to resource constraints. ${ }^{116}$

\footnotetext{
${ }^{113}$ See I. Pernice 'The Treaty of Lisbon: Multilevel Constitutionalism in Action' (2008-9) 15 Columbia Journal of European Law pp349-407 esp at 373 et seq.

${ }^{114}$ This decentralised state of affairs may be contrasted with the far more centralised administration of environmental protection policy in certain federal systems such as the United States, in which the Environmental Protection Agency and Department of Justice have far-reaching powers to intervene in the states for the purpose of safeguarding compliance with federal environmental laws. See e.g. C. Cruden \& B. Gelber, 'Federal Civil Environmental Enforcement in the United States: Process, Players and Priorities', in L. Paddock et al (eds.) Compliance and Enforcement in Environmental Law: Toward More Effective Implementation (Edward Elgar, 2011). Other federal systems of governance may, of course, adopt a more decentralised approach to the regulation of environmental protection like the EU, such as the UK, Germany, Belgium and Australia.

${ }^{115}$ For an overview of EU law in these centralized areas see e.g. Ch3 of P. Craig (2012), n.111 above.

${ }^{116}$ See e.g. J. Pollak \& S. Puntscher Riekmann, 'European Administration: Centralisation and Fragmentation as means of Polity-Building?’ (2008) 31(4) West European Politics pp771-788 at771.
} 
Notwithstanding the fact that implementation of EU environmental law has remained heavily decentralised, it is also clear that the Union has always maintained an interest in overseeing the proper application of EU environmental obligations across Member States.

Administrative autonomy at national level has never been absolute. The Union's constitutional framework has acknowledged this from the outset in various foundational treaty obligations. This is underscored in particular by the so-called 'good faith' clause enshrined within the EU treaty framework contained in Article 4(3) of the Treaty on European Union (TEU), which places a general legal duty on Member States to take active steps to ensure adherence to EU obligations as well as engage in sincere cooperation with the Union for this purpose. ${ }^{117}$ The Court of Justice of the European Union (CJEU) has held that a number of implicit obligations incumbent on Member States (including their competent authorities) relevant to law enforcement flow from Article 4(3) TEU, including: the duty to proceed with same degree of vigilance in detecting breaches of EU law as for national law ${ }^{118}$; the duty to ensure that EU infringements are penalised with effective, proportionate and dissuasive sanctions ${ }^{119}$; and the duty of due diligence to review decision making so as to ensure conformity with EU law. ${ }^{120}$ Union interest in implementation matters is also attested by the EU foundational treaty provisions confirming the supervisory roles vested in the $\mathrm{CJEU}^{121}$ and European Commission ${ }^{122}$ to assist in ensuring the correct application of Union law in the Member States.

The Union has in recent years stepped up the level of its engagement with implementation supervision in the environmental sector, exemplified by a range of initiatives relating to environmental inspections. It has also passed measures stipulating a range of sanctions to be applied for non-compliance with EU environmental law. ${ }^{123}$ These developments represent a

\footnotetext{
${ }^{117}$ Art.4(3) TEU states:

"Pursuant to the principle of sincere co-operation, the Union and the Member States shall, in full mutual respect, assist each other in carrying out tasks which flow from the Treaties.

The Member States shall take any appropriate measure, general or particular, to ensure fulfilment of the obligations arising out of the Treaties or resulting from the acts of institutions of the Union. The Member States shall facilitate the achievement of the Union's tasks and refrain from any measure which could jeopardise the attainment of the Union's objectives."

${ }^{118}$ See e.g. Case C-68/88 Commission v Greece [1989] ECR 2965 (esp. paras.23-24 of judgment).

${ }^{119}$ See e.g. Case C-354/99 Commission v Ireland [2001] ECR I-7657 (at para. of 46 of judgment).

${ }^{120}$ Case C-72/95 Aannemersbedriff P K Kraaijeveld BV [1996] ECR I-5403.

${ }^{121}$ Notably Art.19 (1) TEU and Art.267 TFEU.

${ }^{122}$ Notably, Art.17 TEU and Art.258/260 TFEU.

${ }^{123}$ Notably, by virtue of Directive $2004 / 35$ on environmental liability with regard to the prevention and remedying of environmental damage, n.64 above (criminal sanctions), Directive 2008/99on the protection of the environment through criminal law [2008] OJ L328/28 (administrative sanctions concerning environmental remediation), ETS Directive 2003/87 establishing a scheme for greenhouse gas emission allowance trading
} 
response on the part of the Union to the challenge of upholding the effectiveness as well as legitimacy of federally agreed environmental protection standards in the face of longstanding Member State failures Member State to secure binding EU legislative outcomes. Post-Lisbon, the Union's general constitutional mandate in relation to implementation has been consolidated through the introduction of Article 197(1) TFEU which confirms that 'effective implementation of Union law by the Member States, which is essential for the proper functioning of the Union, shall be regarded as a matter of common interest' (emphasis added).

However, countervailing forces exist in relation to these dynamics. Stubborn resistance expressed by several Member States towards greater levels of federal (EU) involvement in matters of implementation concerning EU environmental policy delivery, has if anything intensified. Paradoxically, as the number of EU environmental measures on implementation (including inspection standards) has increased, Member States have placed greater constitutional checks and obstacles in the way of such developments. In particular, the 2007 Lisbon Treaty has introduced two constitutional mechanisms liable to place potentially significant restraints on moves to increase federal (i.e. Union) involvement in the area of environmental inspections; specifically, the treaty provisions concerning subsidiarity and the limits to administrative cooperation enshrined within the new Title XXIV of Part III of the TFEU.

Subsidiarity ${ }^{124}$ was first introduced as a generally applicable constitutional principle in EU law by virtue of the 1992 Treaty on European Union (Maastricht Treaty), after having been first applied solely to the area of EU environmental policy under the SEA. The definition of subsidiarity is set out in Article 5(3) TEU, which builds in a rebuttable presumption that Member State action is to be preferred over Union intervention in policy fields in respect of which the Union and Member States share competence (such as environment policy).

within the Community as amended, n.46 above (excess emissions financial penalty), Regulation 443/09 setting emission performance standards for new passenger cars as part of the Community's integrated approach to reduce $\mathrm{CO}^{2}$ emissions from light-duty vehicles [2009] OJ L140/1 (as most recently amended by Regulation 2015/6 [ 2015] OJ L3/1) and Regulation 510/2011 setting emission performance standards for new light commercial vehicles as part of the Community's integrated approach to reduce $\mathrm{CO}^{2}$ emissions from light-duty vehicles [2011 OJ L145/1 (as most recently amended by Regulation 404/2014 [2014] OJ L121/1) (excess emissions premium to be paid in the event of exceedance of $\mathrm{CO}^{2}$ emissions target).

${ }^{124}$ For overviews on the evolution and impact of the subsidiarity principle in EU administrative law see e.g. Ch14 of P. Craig (2012) n.111 above and Ch9 of R. Schütze (2015) n.109 above. 
By virtue of Lisbon, the principle of subsidiarity has been significantly strengthened with the establishment of particular powers vested in national parliaments to request or force a review of EU legislative proposals deemed by a minimum proportion of Member State parliamentary assemblies to breach the requirements of subsidiarity set out in Article 5(3) TEU (the socalled 'yellow card' and 'orange card' procedures). ${ }^{125}$ Prior to Lisbon, the subsidiarity principle could only be enforced under the EU treaty framework by way of judicial review before the CJEU, whose case law has confirmed that the principle affords a wide margin of appreciation to the EU legislature in determining whether the Union should be deemed competent to act. ${ }^{126}$ Whilst the conditions attached to the national parliamentary review procedures are challenging ${ }^{127}$ they are by no means impossible to fulfil. Since Lisbon's entry into force in December 2009, the yellow card procedure has been invoked twice, once successfully leading the Commission to withdraw its proposal for a regulation concerning the exercise of the right of collective action within the context of the freedoms of establishment and service provision in September 2012. ${ }^{128}$

In addition to strengthening subsidiarity, the Lisbon Treaty introduced a novel treaty clause expressly limiting the Union's competence to take measures to shore up Member State administrative structures that deal with implementation matters. This limitation has been crystallized in Article 197(2) TFEU under Title XXIV on Administrative Cooperation of Part III of the TFEU which rules out the possibility of the Union adopting harmonising measures

\footnotetext{
${ }^{125}$ Protocol (No2) on the Application of the Principles of Subsidiarity and Proportionality [2012] OJ C326. ${ }^{126}$ See e.g. paragraph 29 of CJEU's judgment in Case C-508/13 Estonia $v$ EP and Commission (judgment of 18.6.2015) in which the CJEU held that with regard to the judicial review of the application of Art.5(3) TEU 'the EU legislature must be allowed broad discretion' in areas which entail 'political, economic and social choices on its part, and in which it is called upon to undertake complex assessments. Consequently, the legality of a measure adopted in that sphere can be affected only if the measure is manifestly inappropriate having regard to the objective which the competent institution is seeking to pursue.' See also Case C-491/01 BAT (Investments) and American Tobacco [2002] ECR I-11453 at paragraph 123 of judgment and Case C-58/08 Vodafone et al [2010] ECR I-4999 at paragraph 52 of judgment.

${ }^{127}$ For the yellow card procedure to be triggered at least a third of the votes allocated to national parliaments must register a negative reasoned opinion within 8 weeks of the national assemblies being notified of the legislative proposal (in accordance with Articles 6 and 7(2) of Protocol (No 2) n.125 above. For the orange card procedure to operate, at a least a simple majority of votes allocated to national parliaments must register a negative reasoned opinion within the same time period (in accordance with Articles 6 and 7(3) of Protocol (No 2)).

${ }^{128}$ The so-called 'Monti II' initiative: COM (2012)130 Commission proposal for a regulation on the exercise of the right to take collective action within the context of the freedom of establishment and the freedom to provide services, 21.3.2012. On the other occasion in which the yellow card procedure has been invoked by national parliaments to date the Commission decided not to withdraw its proposal (COM (2013)534 Commission proposal for a regulation on the establishment of the European Public Prosecutor's Office, 17.7.2013).
} 
concerning improvements of Member States' administrative capacity. Article 197(2) TFEU, which has thus far received relatively little attention in EU institutional practice and amongst academic legal commentators, states:

\section{“Article 197 TFEU \\ $[\ldots]$}

2. The Union may support the effort of Member States to improve their administrative capacity to implement Union law. Such action may include facilitating the exchange of information and of civil servants as well as supporting training schemes. No Member State shall be obliged to avail itself of such support. The European Parliament and the Council, acting by means of regulations in accordance with the ordinary legislative procedure, shall establish the necessary measures to this end, excluding any harmonisation of the laws and regulations of the Member States."

Article 197(2) is complemented by Article 6(g) TFEU, which confirms that the Union has competence to carry out action in the field of administrative cooperation to support, coordinate or supplement the actions of Member States. Article 2(5) TFEU confirms that such supportive, complementary or supplementary competence does not supersede Member State competence (i.e., has no pre-emptive effect). This stands in contrast with areas of Union policy competence shared with Member States (such as environmental policy). ${ }^{129}$ The effect of Article 197(2) TFEU is to act as lex specialis to the general environmental treaty provisions set out in Articles 191-193 TFEU, so as to rule out the prospect of harmonized EU minimum standards regarding the administrative capacity of Member State national environmental protection authorities. The effect of Article 197(2) is to restrict the scope of Article 192 TFEU, which in light of CJEU case law might otherwise be construed as broad enough to provide a legal basis for measures intended to harmonise national rules on implementation which the EU legislature consider necessary to ensure the effectiveness of EU environmental protection rules. ${ }^{130}$

\footnotetext{
${ }^{129}$ Art.4 (2)(e) TFEU.

${ }^{130}$ Notably, in its Environmental Crimes judgment (Case C-176/03 Commission v Council [2005] ECR I-7879), the CJEU confirmed that the predecessor to Article 192 TFEU (Article 175 EC) provided the EU legislature with a legal basis to introduce a directive on environmental crime with a view to ensuring the application of effective, proportionate and dissuasive criminal penalties by competent national authorities, as a reflection of the EU legislature's view that such an instrument constitutes an essential measure for combating serious environmental offences: see paragraph 48 of judgment in Case C-176/03.
} 
At first glance it might seem that Article 197(2) TFEU raises a significant legal question mark concerning the legal validity of a Union legislative instrument seeking to harmonise standards on environmental inspections. It is important to bear in mind, though, that the material scope of this treaty provision covers only measures specifically addressing aspects concerning administrative capacity. Accordingly, the CJEU would likely regard as ultra vires legislative provisions in a Union environmental inspection directive stipulating minimum numbers of personnel, training schemes or communication equipment and networks to be used by national environmental inspection authorities on account of the harmonisation exclusion clause under Article 197(2). However, legislative provisions stipulating minimum operational standards for environmental inspections are not caught by Article 197(2). A suitably narrow interpretation of the material coverage of Article 197(2) is supported when one considers its origins which may be traced back to the European Convention process that culminated ultimately in the drawing up of the failed 2004 Treaty establishing a Constitution for Europe (TECE). ${ }^{131}$ Section 6 of Title III of Part III of the TECE contained an equivalent provision to Article 197(2) TFEU, namely Article III-185. Working Group V of the European Convention process leading up to the adoption of the TECE concerned itself with the area of 'complementary competencies'. In its final 2002 report $^{132}$ to the Convention Secretariat the Working Group recommended that the Union be authorised to facilitate 'exchange of information and persons related to administration of EU law and to support common training and development programmes'. ${ }^{133}$ The final report also refers to a document ${ }^{134}$ of the Working Group containing the original proposal for the facilitation of administrative cooperation, which identifies its aim as the provision 'of a formal framework for Community actions aiming at further strengthening co-operation between and mobility among public administrations across the EU, and at stimulating exchanges and common activities on issues of common concern in the field of public administration, including common training and development activities', whilst also 'making such actions more sustainable and enduring, as well as more transparent and public'. ${ }^{135}$ These documents clarify that the intention behind the Working Group's initiative on administrative co-operation was in essence to facilitate the development of administrative cooperation between national authorities through networks

\footnotetext{
${ }^{131}$ Treaty establishing a Constitution for Europe [2004] OJ C310/1.

${ }^{132}$ CONV 375/1/02 REV 1 (WG V 14) Final Report of Working Group V to the European Convention, 4.11.2002.

${ }^{133}$ See page 18 , ibid.

${ }^{134}$ European Convention Working Group V (working document 21): Proposal by G. Druesne on a new article on Public Administration (4.9.2002).

${ }^{135}$ See page 4, ibid.
} 
(such as the IMPEL network established amongst environmental authorities) and ensure that these would be established on a more formal and accountable footing. There is no evidence to suggest that the Member States came to change this purpose when deliberating over the terms of the TECE, although it is evident that they did agree to incorporate clauses ruling out harmonisation of such measures.

Accordingly, whilst Article 197(2) TFEU serves to restrict the material scope of an EU environmental inspections instrument, the effect of the 'no harmonisation' clause is by no means fatal to its promulgation. ${ }^{136}$ Introduction of Article 197(2) has raised the level of legal complexity in terms of identifying the boundaries of Union competence with respect to the area of national environmental inspections and appears to introduce a limitation of Union competence previously not identified as a priority concern in the particular policy field. Yet it would be an error to construe the purpose of Article 197(2) as being to secure the outright exclusion of Union measures intended to enhance the administrative capability of Member State authorities to secure delivery of EU policy decisions, including in the environmental sector. Indeed, Article 197(3) TFEU underpins the limited scope of Article 197(2) by emphasising that the treaty article is without prejudice to the obligations of Member States to implement Union law. There is no doubt, though, that the EU legislature will have to tread with some caution and comply with the requirements of Article 197(2) if presented with the opportunity to deliberate upon a legislative proposal concerning the general management of national environmental inspection systems to oversee compliance with EU environmental law. Furthermore, given its uncertain parameters, it is highly likely that Article 197(2) TFEU would become a bone of legal contention in judicial review proceedings before the CJEU if Union political institutions and Member States fall out over the contents of any future general horizontal EU legislative instrument intended to supersede the RMCEI.

\section{CONCLUDING REMARKS}

Although the EU has managed to adopt a number of measures on environmental inspection management, it has so far not established a sufficiently coherent supranational federal

\footnotetext{
${ }^{136}$ Schütze has cautioned that an ironic side-effect of this treaty provision may be to favour indirectly more centralized intervention by the EU through the conferral of implementing powers on the Commission or Council of the EU under the aegis of Article 291(2) TFEU (i.e. via 'comitology'): R. Schütze (2015) n.109 above at p339. In the context of EU environmental policy, though, such a development is unlikely given the longstanding resistance and scepticism of several Member States to the idea of a strong level of supranational institutional engagement in implementation matters.
} 
framework upon which to develop Union policy in this area. Whilst a number of key environmental sectors have not yet been made subject to minimum Union standards concerning inspection management (e.g. water, nature protection, air quality), the existing range of Union legislative provision on environmental inspections appears to have developed with little regard for consistency. The process for developing a viable general framework instrument has so far proved to be a tortuous process. The RMCEI is not fit for purpose, being neither legally binding nor adequately broad in material scope. It remains unclear when a successor measure will proposed, notwithstanding the adoption of a clear political mandate for legislative revision by the EAP7. As a consequence of widespread Member State scepticism of moves to construct a broad and effective supranational framework on environmental inspections, a view which appears also to resonate with the current European Commission college (2014-2019), Union policy on environmental inspections has remained to date incremental, unpredictable and uncoordinated.

The slow progress made by the Union towards a more effective system of shared management between EU federal and Member State levels over inspections is reflective of the unclear and unsettled position of the EU on the issue of balance of power and responsibilities between each level of governance operating across the Union. In essence, the Union remains subject to contradictory influences regarding the question of federal involvement in oversight and control of administration of inspection systems. On the one hand, the poor record of implementation of EU environmental obligations has to some extent strengthened the hand of those questioning the credibility of continuing with the traditional model of 'indirect administration' which favours a predominance of Member State administrative autonomy. Such questioning has emanated notably from the Commission's Environment Directorate General as well as the European Parliament. The Lisbon Treaty has also underpinned the legitimacy of a role for the Union to concern itself with implementation matters in the form of Article 197(1) TFEU, in confirming that Member State implementation is to be regard as a 'matter of common interest' and 'essential for the proper functioning of the Union'. On the other hand, countervailing political and constitutional dynamics within the Union continue to offer considerable resistance against increases in supranational engagement in policy. Political resistance is given expression in the form of Member State representation in the Council of the EU. Constitutional resistance is expressed in the form of Union treaty provisions on subsidiarity guarantees and an exclusion of harmonisation regarding the area of national administrative capacity under Article 197(2) TFEU. With these 
conflicting forces in play, it is unsurprising that it remains problematic for headway to be made over future development of EU policy on environmental inspections management. In the absence of a clear(er) resolution of how federal and statal roles should be defined, it is likely that the Union will be unable to achieve a genuinely integrated and effective form of shared administration within the European administrative space as far as environmental inspection management is concerned. Moreover, unless the Union establishes a more coherent supranational framework on environmental inspections, it is difficult to see how significant progress will be achieved in addressing the current poor state of implementation of EU environmental law. 